\title{
Hagia Sophia: \\ Symbol of Peace and Diversity
}

\author{
YAVUZ SELIM KIRAN \\ Deputy Minister of Foreign Affairs, Turkey \\ ORCID No: 0000-0002-0619-0875
}

\begin{abstract}
On July 10, 2020, the Council of State revoked a 1934 Cabinet decree that had turned Hagia Sophia into a museum, thereby paving the way to restoring its former function. The decision was welcomed by the overwhelming majority of Turkish people, government or opposition supporters alike. Some criticized the decision by creating a false impression that Turkey is turning its back on religious tolerance and diversity. The functional change of Hagia Sophia will have no effect on Turkey's centuries-old tradition of promoting tolerance, harmony, and diversity. Hagia Sophia will continue to embrace and unite everyone as a symbol of tolerance, peace, and dialogue between cultures and religions.
\end{abstract}

Keywords: Hagia Sophia, Cultural Heritage, Islam, Diversity, History

Insight Turkey 2020

Vol. 22 / No. 3 / pp. 67-73 


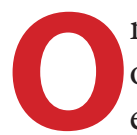
n July 10, 2020, the Council of State (Danıştay), the highest administrative court in Turkey, revoked a 1934 Cabinet decree that had turned Hagia Sophia, a UNESCO World Heritage Site since 1985 and part of the Historic Areas of İstanbul, into a museum. The Court's decision was followed by a decree signed by Turkish President Recep Tayyip Erdoğan to reopen the monumental building as a mosque after a hiatus of 86 years. The decision was welcomed by the Turkish and Muslim world with excitement.

As our Foreign Minister Mevlüt Çavuşoğlu has made it clear that, the issue of Hagia Sophia's status is not an international matter but is a matter of national sovereignty for Turkey. Hav-

\section{Thanks to Turkish control and} maintenance of the property, today we still have a treasure of architectural magnificence called Hagia Sophia

ing said that, in order to demonstrate the extent to which the claims regarding the functional transformation of Hagia Sophia are unfounded and biased, we hosted a tour to the Grand Mosque of Hagia Sophia for a number of Ambassadors and Heads of International Organizations to Turkey on August 6-7, 2020. This tour was an invaluable opportunity for all of the participants to see first-hand this great masterpiece in its current status. After the tour, we met with the distinguished participants at a working dinner where Turkey's enterprising and humanitarian foreign policy was also discussed. In the following paragraphs, readers will find some of the points that I shared with the Ambassadors and other participants regarding the recent steps taken by the Turkish authorities on the status of Hagia Sophia, a landmark that has graced the magnificent silhouette of İstanbul for nearly 1,500 years.

\section{Eighth Wonder of the World}

One of the most important common goals of humanity should be to preserve cultural heritage sites of universal value. Hagia Sophia, which means 'Sacred Wisdom,' is one of the most extraordinary architectural monuments in existence, and has even been described as the Eighth Wonder of the World. It goes without saying that the Republic of Turkey and its historical predecessor the Ottoman Empire have long been aware of its outstanding cultural, historical and spiritual value in all senses and have, for centuries, protected, renovated, and fortified this sanctuary accordingly.

Among the most majestic architectural structures of the Byzantine era, Hagia Sophia, remained a church for more than 900 years and hosted many significant events. Although the building survived natural disasters, including huge earthquakes, a large number of its collections and priceless artifacts were looted during the invasion by the Crusader Army in 1204, at which time the structure was also desecrated. 


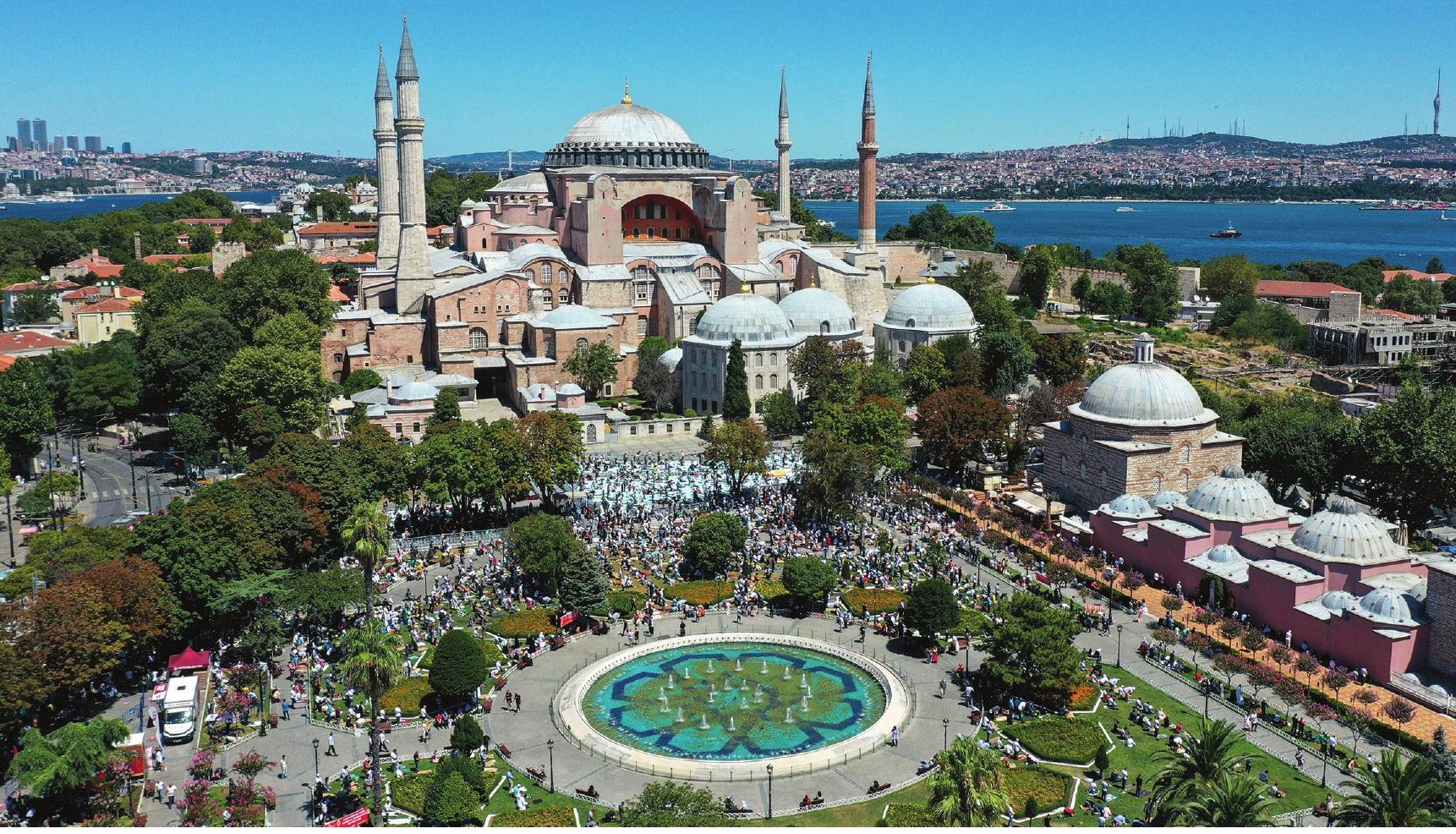

Historical records show that when İstanbul was conquered by Ottoman Sultan Mehmet II, 'the Conqueror' (Fatih) in 1453, he headed directly to Hagia Sophia where the local residents had taken refuge, to let them know that their lives and properties would be safe and untouched. Unlike the $13^{\text {th }}$ century looting and pillaging, or the poor and dilapidated state of the building before the time of the Ottoman conquest, Ottoman Sultans did their utmost to repair and maintain the edifice where they performed their Friday prayers. Thanks to Turkish control and maintenance of the property, today we still have a treasure of architectural magnificence called Hagia Sophia.

Following the conquest, Hagia Sophia was transformed into a mosque and served as such for almost half a millennium, while remaining the property of the Fatih Sultan Mehmet Endowment until it became a museum in 1934. According to Turkish Law on Endowments, a property should primarily be used pursuant to the function written in its founding document (waqfiye). In that regard, it should be noted that even at the time when the decision was made to turn Hagia Sophia into a museum in 1934 , the building continued to remain a mosque in the Land Registry.

Based on the aforementioned Turkish Law of Endowments, a local NGO appealed to the Turkish Council of State, requesting that the decision of the Council of Ministers of 1934 be revoked. After due process, the highest administrative court decided for the annulment by restituting Hagia Sophia into its former legal status, namely a mosque, as it is registered in the endowment.

So, what has changed now that Hagia Sophia has been reverted into a
The fourth Friday prayer at Hagia Sophia-i Kebir Mosque-i Şerifi was held with large numbers of worshippers who filled the mosque and its surroundings, August 14, 2020.

Muhammed Enes YIIdırım / AA 
While EU pressure definitely played some role in pushing Moscow to engage in price concessions, there were other, possibly even more important reasons for Gazprom's concessions
Following the court decision, the Presidency of Religious Affairs and the Ministry of Culture and Tourism signed a protocol which states that the Ministry of Culture and Tourism is responsible for the preservation of the outstanding universal value of Hagia Sophia, just as before, while the Presidency of Religious Affairs will be responsible for the religious services that take place there. Naturally, some necessary measures must be taken in order to allow prayers. Accordingly, some mosaics will be covered with a curtain system during the prayer times, with utmost care to the majestic architectural design of the building. The imperial coronation zone is not included in the prayer area. These measures demonstrate the willingness of the Turkish state to maintain the significance of the monument as a symbol of intercultural harmony. These steps are in accordance with the 1972 World Heritage Convention which does not prejudice property rights or their change of functions. In our view, the process was carried out in full accordance with the 'Operational Guidelines for the Implementation of the World Heritage Convention, as it involved no major permanent restorations or new constructions that might affect the outstanding universal value of the property, which would have required prior notification of the World Heritage Committee by the State Party at the planning stage.

As an active member of UNESCO, Turkey attaches importance to its relations with this prominent $\mathrm{UN}$ organization. In this context, our coop- 
eration and the flow of information with UNESCO and the World Heritage Centre is operational and wide open. Our Permanent Representative to UNESCO has already held several meetings with UNESCO authorities. The change of Hagia Sophia's status is in keeping with the Convention Concerning the Protection of the World Cultural and Natural Heritage and the Operational Guidelines. Furthermore, the Turkish Ministry of Culture and Tourism maintains a line of communication with UNESCO authorities. In this vein, a visit to Hagia Sophia by UNESCO and ICOMOS experts is currently being coordinated.

As President Erdoğan has emphasized, "It is our duty to preserve our cultural heritage for future generations." Hagia Sophia is a unique example of our efforts in this context. It has stood the test of time and survived until today with its all cultural layers and value, thanks to the protection measures taken by the Republic of Turkey and its predecessor the Ottoman Empire, including the work of master architect Mimar Sinan and the renovations made by Swiss architect Gaspare Fossati upon the decree of Sultan Abdulmejid.

It is unfortunate that those who criticize Turkey are not advocates of cultural heritage and freedom of religion when it comes to the Ottoman heritage in their own countries. Many Ottoman mosques across the world have either been destroyed or converted into churches, and others are being used in a way that does not serve their original purpose of construction. Turkey, therefore, deeply regrets the statements that ignore the heartfelt embrace of Hagia Sophia by our country and all the conservation measures taken to maintain the value and significance of this architectural masterpiece. The protection and conservation of Hagia Sophia, with its amazing frescoes, exquisite mosaics, and other cultural assets will continue to be carried out meticulously.

\section{"Peace at Home, Peace in the World"}

Turkey pursues a foreign policy guided by its founding principle "Peace at Home, Peace in the World" with an 'enterprising and humanitarian' approach to achieve security, stability, and prosperity in its neighborhood and beyond, thanks to its immense potential and growing means and capabilities. Turkey aims to achieve positive and concrete results at the regional and international levels, strengthen peace, security, stability and sustainable development.

The main priorities of Turkish foreign policy include advancing its strategic relations, promoting crisis management and stability, protecting the rights of Turkish citizens and kindred peoples abroad, fighting against terrorism, developing ties with all geographies through regional outreach policies, strengthening economic-commercial relations and energy security, increasing cooperation with 


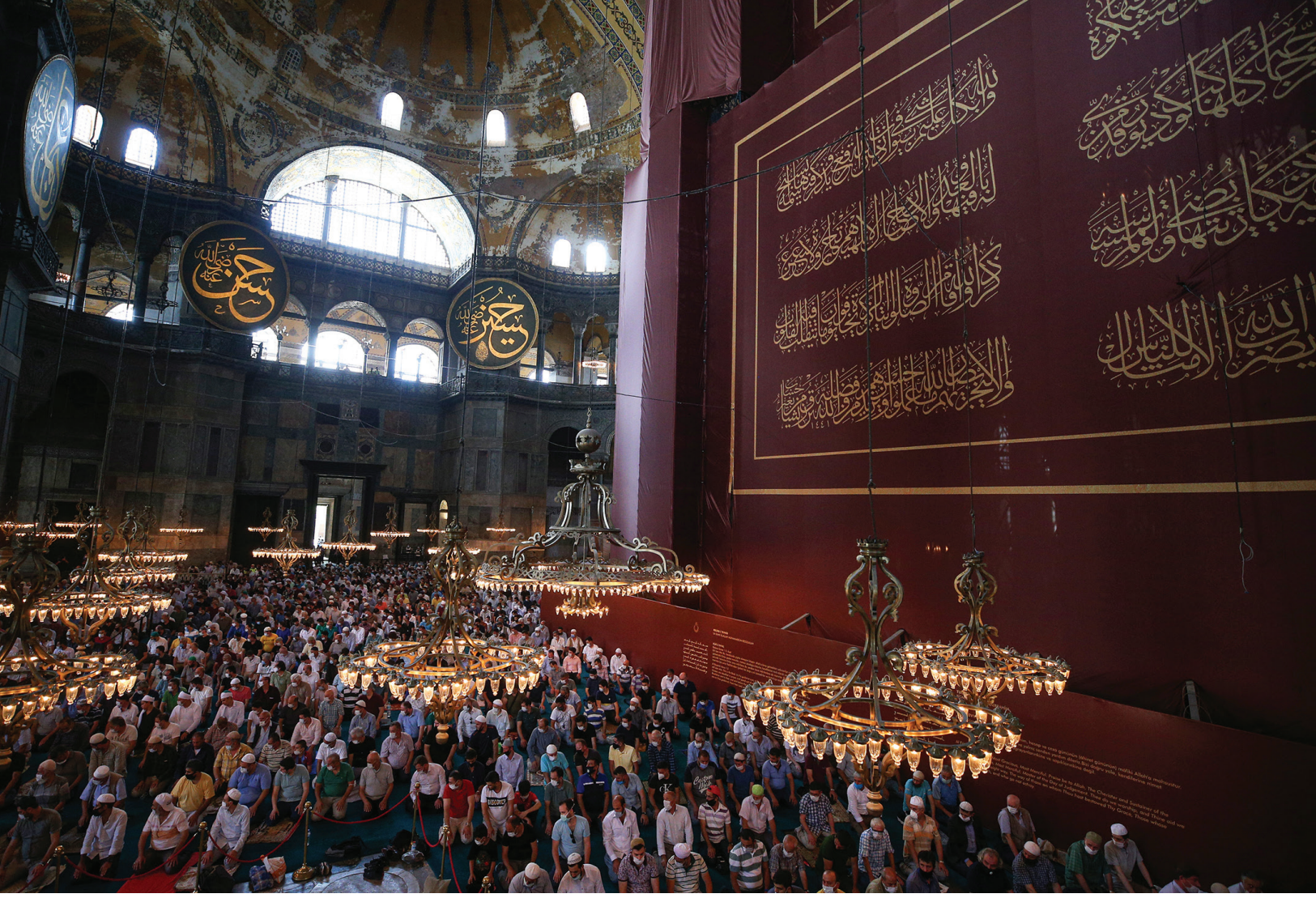

First Friday prayer

in 86 years being performed at the Hagia Sophia-i Kebir Mosque-i Şerifi, which was re-opened for muslim worship, July 25, 2020.

Muhammed Enes Yıldırım / AA global and regional organizations and enhancing its soft power. With its 246 missions, as the fifth largest diplomatic network across the world, Turkey believes that multilateralism and collective efforts are essential to resolving global issues.

The foreign policy of the Republic of Turkey will continue to safeguard Turkey's national security and interests while contributing to the common goals of humanity, including the preservation of cultural heritage sites of universal value.

Turkey adheres with great dedication to its legacy of multi-faith tolerance and cultural pluralism. Our constitutional system is based on equality before the law. Fundamental rights and freedoms are enjoyed and exercised individually in accordance with the law. Our constitution and legislation protect freedom of religion, con- science, religious belief, conviction, expression and worship, prohibiting discrimination based on religious grounds. Thus, Turkish citizens belonging to different faith groups enjoy and exercise the same rights and freedoms as the majority.

Currently, there are nearly 435 churches and synagogues open for worship across the country. Numerous places of worship that had been closed to service for many years have been reopened following restoration works funded from Turkey's national budget with Turkish taxpayers' money in recent years, albeit in a predominantly Muslim nation. This shows how firmly and sincerely Turkey embraces religious diversity.

In just the last decade, 15 churches and synagogues across Turkey have been refurbished by the relevant Turkish authorities. These include the Grand 
Synagogue in Edirne, which is the largest synagogue in the Balkans and the third largest in Europe, the Sveti Stefan Bulgarian Church in İstanbul, known as the Iron Church, the Hagia Nicola Church in Gökçeada, the Syriac Catholic Church in İskenderun, the Armenian Protestant Church in Diyarbakır, the Nizip Fevkani Church in Gaziantep, the Taksiyarhis Church on Cunda Island and the Hagia Yorgi Church in İstanbul. Most recently, the Sumela Monastry in Trabzon has been reopened to visitors following five years of renovation work. The Akdamar Armenian Church in Van, which dates back over a thousand years, was previously restored through carefully performed meticulous and professional work.

Last year, upon the instructions of President Erdoğan, a piece of land was allocated to the Assyrian Christian community to build a new church in İstanbul. This will be the first-ever Assyrian church to be built in Turkey in the Republican era. Furthermore, the Mar Petyun Chaldean Church and the Middle East's largest Armenian church, the Surp Giragos Church, both damaged in attacks by PKK terrorists in Diyarbakır's Sur, are currently under restoration.

In addition to these and other restorations, religious minorities may register their properties and in some cases receive financial restitution, thanks to amendments in the Law of Foundations that was enacted in 2011. Since then, 333 properties have been registered, and compensation has been paid for 21 properties.
Hagia Sophia will continue to embrace and unite everyone as a symbol of peace and diversity between cultures and religions. Our efforts for the preservation and sustainable management of our World Heritage Properties, including Hagia Sophia, will continue unabated

\section{Conclusion}

To reiterate, in our Foreign Minister Çavuşoğlu's words, "all decisions regarding Hagia Sophia are a matter of national sovereignty." The functional change of Hagia Sophia, however, will have no effect on Turkey's centuries-old tradition of promoting tolerance, harmony and diversity. On the contrary, it will further increase dialogue by applying an opendoor policy to everyone regardless of religious, national or racial background. As its name 'Sacred Wisdom' suggests, Hagia Sophia is the place where believers gather to benefit from the divine wisdom. Hagia Sophia will continue to embrace and unite everyone as a symbol of peace and diversity between cultures and religions. Our efforts for the preservation and sustainable management of our World Heritage Properties, including Hagia Sophia, will continue unabated. 


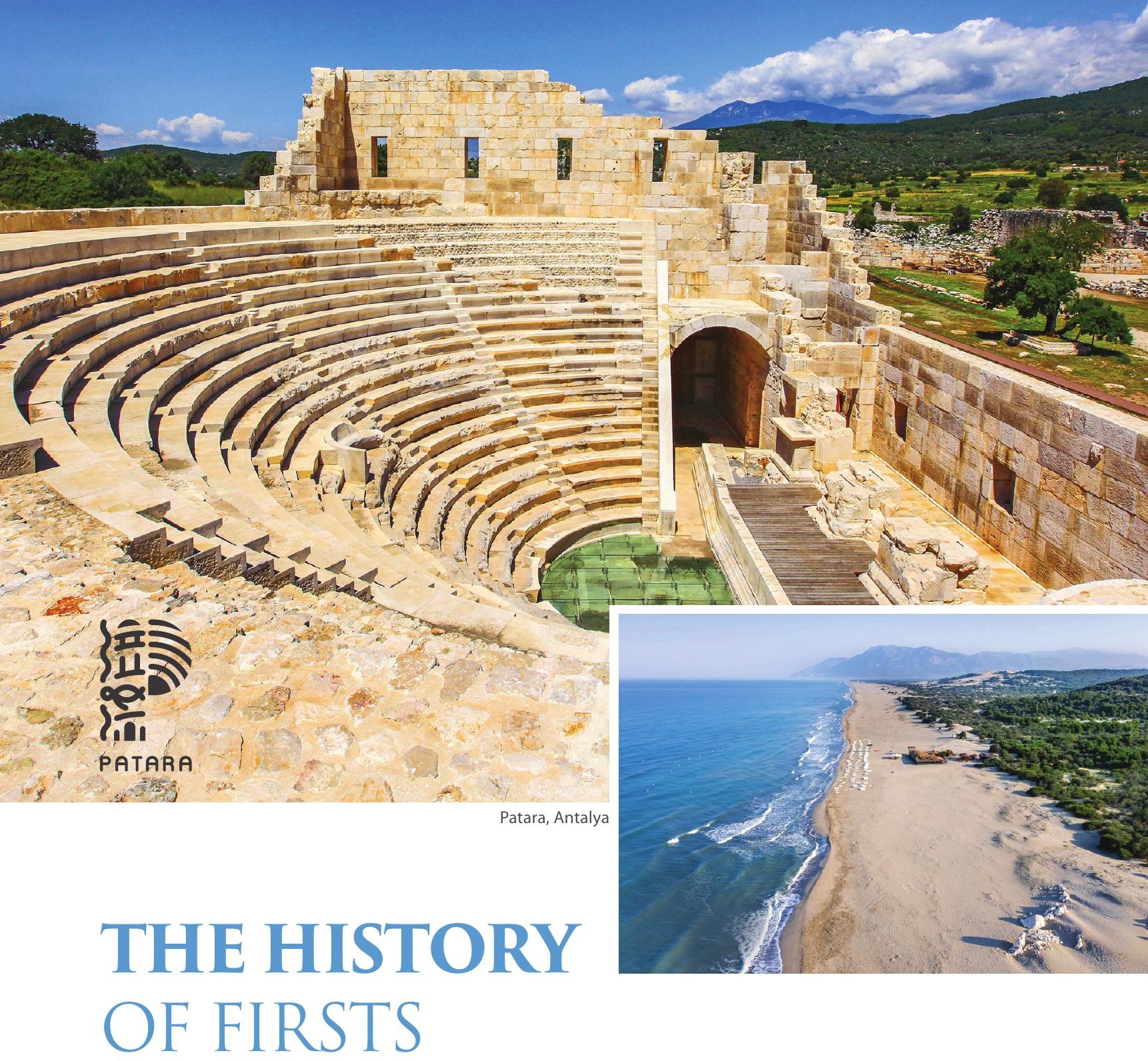

Patara, one of the most important ancient cities of the

Mediterranean region, is the cradle of 'Firsts' in history with;

a parliament building symbolising the perfect republican model, the only emperor lighthouse remaining from Anatolian ancient times, the birth \& living place of Saint Nicholas (Santa Claus) and a $12 \mathrm{~km}$-long beach hosting caretta carettas for millions of years.

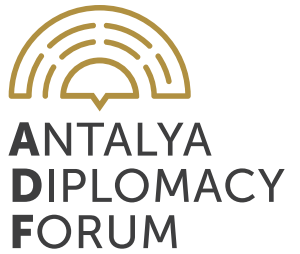

